\title{
Inventory for Ethnovegetable Knowledge of the Tribals from Satpura Hill Area- Melghat, Dist. Amravati (India)
}

\author{
Devarkar V. D. \\ ${ }^{2} \mathrm{Head}$, Department of Botany, Shri Chhatrapati Shivaji College, Omerga Dist. Osmanabad (MS) India \\ Corresponding author: devarkar28@gmail.com
}

\section{Manuscript Details}

Manuscript submitted: 16/04/2018

Manuscript Accepted : 18/04/2018

Manuscript Published : 15/05/2018

\section{Available On}

https://plantaescientia.website/ojs/ DOI: https://doi.org/10.32439/ps.vli0l.1-8

\section{Cite This Article As}

Bhogaonkar P Y \& V D Devarkar, (2018). Inventory for ethnovegetable knowledge of the tribals of Satpura hill area-Melghat, Dist. Amravati (India), Pla. Sci. 2018; Vol. 01 Issue 01: 01-08.

\section{Copyright}

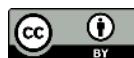

(c) The Author (s). 2018 Open Access This article is distributed under the terms of the Creative Commons Attribution 4.0 International License http://creativecommons.org/licenses/by/4.0/

\section{Indexed In}

Crossref, Google Scholar, Index Copernicus International (ICI), Directory of Research Journal Indexing (DRJI)

\begin{abstract}
The present inventory carried out in Melghat region falling in Satpura ranges. While collecting ethnobotanical information regarding medicinal plants, the valuable information about the vegetable use of plants noted and presented in this paper. A total of 189 ethnomedicinally important plants Melghat were surveyed using a schedule to assess the knowledge, availability and consumption pattern of wild leafy vegetables. The study revealed 30 ethnovegetable plants of regular use in the food preparation of Korku. The diversity of wild leafy vegetables being used by the local inhabitants is 30 species belonging to 20 genera and 17 families. The majority of ethnovegetable plants were herbs the majority of the ethnovegetable plants used by Korku tribe in the study area were collected raw from the forest as wild and not cultivated ones. The study indicated that the knowledge is to be transferred properly by old people to the younger generation and should be trained in collection and processing of such wild ethnovegetables. The record of 30 ethnovegetable plant species shows that Korku of Melghat is a distinct tribe. Another feature of Korku usage of plants as drugs is that the use of monocots is frequent in their system as compared to other tribes. Here, out of 30 plant species, 08 are from the monocot.
\end{abstract}

Keywords: Ethnovegetables, Ethnobotany, Korku, Tribals of Satpura, Melghat 


\section{INTRODUCTION}

There is no culture on this planet that has not made use of plants for physical, emotional and spiritual needs of human life. Plants form an integral part of any society any time. In remote rural societies where vegetable cultivation is not practiced and the market is not available for local inhabitants, they should be dependent on locally available plants those can be used as vegetables. Consumption of green vegetables is a chief source of vitamins and micro-nutrients for those who are vegetarian. Knowledge of these edible plants is part of their traditional knowledge which is usually transmitted by elders to young ones and also by participation of individuals in the collection of vegetable plants. Availability observations were done using regular visits with informants. Use of plants for one or other purpose is done by the human societies since very long period While, the hunter-gatherer societies still continue to profess such lifestyles, the agricultural societies did not eliminate the use of non-cultivated resources. Nowadays, human vegetable consumption is based on rather very limited number of crops (12-15 species) but in many parts of the world the use of wild plants is very common (Scherrer AM, et al, 2005; Bussmann et al, 2006; Bussman \& Sharon, 2006; Kunwar et al, 2006). Surveys were done by Food \& Diet-related aspects never considered wild edible plants as vegetables. They only concentrated on cultivated vegetable species. (Pieroni et al, 2007). Wild plants can be the best genetic resources as they are relative to the most cultivars. They can be useful in case of genetic erosion or for crop improvement (Kala, 2007). Changing social values, depopulation of rural areas is a main reason for the erosion of traditional knowledge. Many publications (Kala, 2007; Lindeberg et al, 2003; Sundriyal \& Sundriyal 2001, 2003; Nautiyal et al, 2003; Dhyani et al 2007) have emphasized on the diversity and value of traditional vegetables. The nutritional value of traditional leafy vegetables is higher than several known vegetables. Most of these ethnovegetables have a potential to compete with cultivated vegetables. Consumption of traditional diets known to these societies is said to have many beneficial effects such as prevention of some age related degenerative diseases - arteriosclerosis, stroke, etc. (Lindeberg et al 2003). Despite these advantages, most traditional plant foods are generally uncultivated and underutilized (Kunwar et al, 2006; Grivetti \& Ogle, 2000).

\section{STUDY AREA}

The study area is situated on the branch of Satpuda range to the south of Tapti River. The prominent feature is the main ridge of Gawilgarh hills. Reserve forest of Melghat division is divided into East Melghat and West Melghat division. It stretches from south to north between latitudes $21^{\mathrm{O}}-1 \mathrm{l}^{\prime}$ and $21^{\mathrm{O}}-46^{\prime}$ north and from west to east between longitude $78^{\circ}-38^{\prime}$ and $77^{\circ}-34^{\prime}$ easts. It turns to the southwest and widens into Chikhaldara and Vairat plateau with summit levels of 100 meters. Vairat is the highest point being 1,177.75 meters above MSL.

The striking feature of Melghat ride is its almost flat-topped plateau descending in a series of precipitous scarps on either side, one below the other, separated by narrow steps of lesser gradients and finally sloping down to the narrow step valleys known as Khoras. Numerous spurs branch off from this main ridge towards north and south, having narrow ridges known as Ghors or Dhars and flat tops known as Ballas. The valleys just north to the main ridge are very deep but later on they gradually widen where the best forest of the region occurs. Melghat Sub-Division of Amravati district comes under Tribal Sub Plan Area.

Entire area comes under category I. i.e. where tribal population are over 50\%. Tribal Sub Plan Area extends over an area of $4212 \mathrm{sq} . \mathrm{km}$. out of which $77 \%$ area is under forests. About 80\% populations is of tribals (Indurkar, 1992).

Melghatis are predominantly scheduled-tribes. These are - Korkus, Gonds and Nihals, Balai are scheduled cast. Besides these Gaolis and Gaolans also have their settlements in Melghat. Majority of the villages residing within Tiger Reserve are Korkus. Percentage of Gonds, Balais, Gaolis and Nihals is limited. Gonds and Nihals are minority. Gaolis are a progressive community. They claim that fort of Gawilgarh was constructed by their ancestors (Ladkat \& Chapkar, 1992).

An abstract of the details of the Korkus tribe is given in the Maharashtra State Gazetteers (1968). Accordingly, Korkus are of Kolarian origin. In language and general type, they are said to be identical with the Kols and Santhals. These days they commonly speak Hindi. The Korkus who first came to Berar found Nihals in the possession of Melghat hills. Gradually the later caste lost their power because the villages drudge of the former. However, it is not clear how and why Korkus came to Berar. According to another theory, Korku are the basically nomadic tribe. Word Korkus is derived from two words Koo $=$ land and $K u=$ the one who walks i.e. Korkus is the one who walks on lands, means a nomadic person. Also, Karo means an honest person. Another meaning of Karo according to some is Kaurav. According to the same soldiers from Kaurav after defeated by Pandavas came to Melghat and their descendants are those Korkus. It also means a folk Kor means Man $\&$ Ku means gathering (Pohar, 1981). 
Study area Map

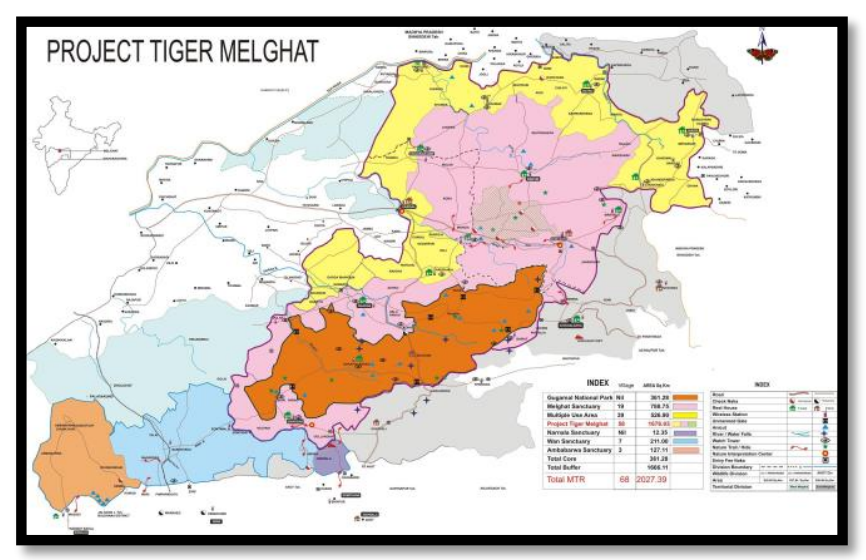

Medicinal uses of the plants used by tribal people, the diversity of wild food plants available for use was documented. Informal discussions, interviews, and village walk with informants, medicine men were held to enhance understanding and gather information about different species of wild vegetable plants available around the villages and in cultivated areas. During 1997-1998 the author surveyed this area. A schedule was used to collect information on personal data, traditional knowledge about each species used by the housewives. Adult female member from the house, who is responsible for the vegetable preparation, was considered as the respondent with additional information from children and men those assisting in collection and processing of wild leafy vegetables. Field visits were made with the informants for the collection of specimens.

Identification of the collected specimens was made with the help of Flora of Melghat (Patel, 1968; Dhore \& Joshi, 1988; Bhogaonkar \& Devarkar, 1999) and other Standard Floras (Gamble, 1919; Hooker, 1872-1897; Mukherjee, 1984; Almeida, 1990; Naik, 1998; Sharma et al, 1996; Singh \& Karthikeyan, 2000). Herbarium specimens were deposited in the Govt. Institute of Science and Humanities, Amravati (Maharashtra) in Department of Botany. Botanical Survey of India, Pune was also consulted for identification and confirmation of identification of the specimens. However, during the visits to each, the author personally accompanied the informant to the fields to document the extraction, processing, and preparation. Using the information supplied by the informants the amount of ethnovegetables harvested by each family is estimated.

\section{OBSERVATIONS}

Ethnovegetables were collected and information about parts used in preparation are mentioned here.
Abelmoschus ficulneus (L.) Wt. \& Arn. MALVACEAE

(Kor.- Jangli Bhendi \& Harjud)

Occurrence - Occasional in fences around fields and on hill slopes. Flrs. \& Frts - July - October

Ethnovegetable use - Young leaves and Fruits are used for the vegetable preparation

\section{Abrus precatorius L. FABACEAE (Kor. Gunchi)}

Occurrence - Occasional in fences around fields and on hill slopes. Flrs. \& Frts - July - December

Ethnovegetable use - Inflorescence \& flowers are used for the vegetable preparation

\section{Agave americana L. AGAVACEAE (Kor. Ketaki)}

Occurrence - Occasional in fences and on hill slopes.

Flrs. \& Frts - December to March

Ethnovegetable use - Flower buds \& young flowers are used for the vegetable preparation

Amaranthus spinosus L. AMARANTHACEAE (Kor. Kata)

Occurrence - Ample, Everywhere.

Flrs. \& Frts - August to December

Ethnovegetable use - Young stem and leaves are used for the vegetable preparation.

\section{Amaranthus viridis L. AMARANTHACEAE (Kor. Tamba)}

Occurrence - Ample, Everywhere.

Flrs. \& Frts - August to December

Ethnovegetable use - Young leaves are used for the vegetable preparation

\section{Bauhinia vahlii Wight \& Arn. CAESALPINIACEAE}

(Kor.- Bhosai, Dhondri)

Occurrence - Scattered throughout.

Flrs. \& Frts. - November - January.

Ethnovegetable use - Young leaves are used for the vegetable preparation.

Korku uses - Roasted seeds are eaten to suppress hunger at least for 3-4 hours.

Bauhinia racemosa L. CAESALPINIACEAE (Kor. Mahulvel) Occurrence - Scattered throughout.

Flrs. \& Frts. - November - January. 
Ethnovegetable use - Young leaves are used for the vegetable preparation.

Korku uses - Bark decoction given in rheumatism.

\section{Bauhinia variegata L. CAESALPINIACEAE}

(Kor.- Champa, Mahul,)

Occurrence - Scattered throughout.

Flrs. \& Frts. - November - January.

Ethnovegetable use - Young leaves are used for the vegetable preparation.

Korku uses - Leaf decoction given in 'Vata'.

\section{Begonia crenata Dryand. Hook. BEGONIACEAE}

(Kor.- Khattibhaji)

Occurrence - Occasional on humus rich, wet vertical cliffs, along the streams and river banks and in valley bottoms.

Flrs. \& Frts. - September - October.

Ethnovegetable use - Leaves are sour in taste. Used for pickles, salads and for the vegetable preparation.

Korku uses - Leaf juice taken internally to cure acidity.

\section{Cassia fistula L. CAESALPINIACEAE}

(Kor. - Banag, Bangru, Bhanak - Bhungru Ban Bhungdu)

Occurrence - Throughout common in Melghat.

Flrs. - March - June, Frts - October- February

Ethnovegetable use - Inflorescence (Flowers is all stages) is used for the vegetable preparation.

Korku uses - Root powder with milk given to ladies after delivery to gain strength.

\section{Cassia hirsuta Linn. CAESALPINIACEAE}

( Kor.- Devtorthan, Ver.- Devtarota)

Occurrence - Rare; along the roadsides and interior to Chikhaldara - Semadoh. Flrs. \& Frts. - June - December.

Ethnovegetable use - Young leaves and pods are used for the vegetable preparation.

Korku uses - Root powder made into the paste and applied over skin affections and in leucoderma. Young leaves eaten as vegetable in rheumatism

Cassia tora L. CAESALPINIACEAE (Kor. Torthan) Occurrence - Abundant. Flrs. \& Frts. - June - December.

Ethnovegetable use - Young leaves and pods are used for vegetable preparation.

Korku uses - Young leaves eaten as the vegetable in rheumatism

\section{Dendrocalamus strictus Nees. POACEAE}

(Kor. - Iudo, Mar.-Velu, San.- Venu, Hin. - Bans, Eng. - Male bamboo ) Occurrence - Gregarious in Melghat

Flrs. \& Frts. - No seed. Mass flowering noted during 1959 1981, $1984 \& 1992$.

Ethnovegetable use - Fresh sprouting young shoots are used for the vegetable preparation

Korku uses - The exudate collected from young cut shoots, with powder of Andrographis paniculata is given in diabetes.

\section{Dioscorea belophylla (Prain) Haines. DIOSCOREACEAE} (Kor.- Kandar, Ver. Jangli matol, Karu kand, Nand kand).

Occurrence - Fairly common in Melghat.

Flrs. \& Frts. - September - December.

Ethnovegetable use - Tubers after boiling with tamarind used for the vegetable preparation.

Korku uses - Tuber powder given in heat problems. Tuber poultice applied on Whitlow.

Dioscorea bulbifera L. DIOSCOREACEAE (Kor. Bayal) Occurrence - Fairly common in Melghat.

Flrs. \& Frts. - September - December.

Ethnovegetable use - Bulbils and tubers after boiling with tamarind used for the vegetable preparation.

Korku uses - Tuber powder given general debility and diabetic condition.

Celosia argentea L. var argentea L. AMARANTHACEAE (Kor. - Silgi zara, Saigatya)

Occurrence - Throughout frequent as weed of fields.

Flrs. \& Frts. - September - November

Ethnovegetable use - Young tender leaves used for the vegetable preparation.

Korku uses - Plant decoction given in urinary problems.

Chlorohytum breviscapum Dalzell. LILIACEAE (Kor. Pulum musali)

Occurrence - Fairly common moist slopes, plateau and mud flats along streams margins. Flrs. - Frts. - June - August.

Ethnovegetable use - Young leaves are used for the vegetable preparation.

Korku uses - Tubers taken with milk to strengthen general health and in seminal debility. 


\section{Chlorophytum glaucum Dalzell. LILIACEAE}

(Kor. Pulum musali)

Occurrence - Fairly common in several localities, on moist slopes, plateau and mud flats along streams margins.

Flrs. - Frts. - June - August.

Ethnovegetable use - Young leaves are used for the vegetable preparation.

Korku uses - Tubers taken with milk to strengthen general health and in seminal debility.

\section{Chlorphytum tuberosum (Roxb.) Baker LILIACEAE}

(Kor.- Turshi, Ver. Safed musali, kuli, Ganjagata)

Occurrence - Fairly common in several localities, on moist slopes, plateau and mud flats along streams margins.

Flrs. - Frts. - June - August.

Ethnovegetable use - Young leaves are used for the vegetable preparation.

Korku uses - Tubers taken with milk to strengthen general health and in seminal debility.

\section{Chlorophytum glaucum Dalz. LILIACEAE}

(Kor.- Pulum musali)

Occurrence - Rare, only collected from Dhargad, Gullarghat range. Flrs. - Frts. - July - August.

Ethnovegetable use - Young leaves are used for the vegetable preparation.

Korku uses - Tubers are nutritious; but used to cure sexual impotency.

\section{Ensete superbum (Roxb.) Cheesm. MUSACEAE}

(Kor.- Jangli kela, V. Jangli kela, chowani, )

Occurrence - On all higher precipitous slopes, on rocks.

Flrs. - Frts. - September - November

Ethnovegetable use - Rhizomes and central core of Inflorescence used for the vegetable preparation.

Korku uses - Water from the stems or petiole/sheathing base is used to nullify the effect of alcoholic drinks. Seeds are given to develop permanent sterility in males.

Ficus benghalensis L. MORACEAE (Kor. - Wora)

Occurrence - Occasional throughout.

Flrs. \& Frts. - February-June \& November - January

Ethnovegetable use - Young green fruits are used for the vegetable preparation.

Korku uses - Milk of plant collected on sugar crystals and given daily for one month in seminal debility to increase sperm count. Latex from the plant rolled into ball and the later lightly touched inside the eye to cure soreness.

Ficus religiosa L. MORACEAE (Kor.- Pipari)

Occurrence - Occasional throughout. Receptacles February - May

Ethnovegetable use - Young tender leaves are used for the vegetable preparation.

Korku uses - Root powder with the juice of rhizome of Costus speciosus given to cure asthma.

Lannea coromandelica (Houtt.) Merr.

ANACARDIACEAE (Kor. Kekedo)

Occurrence - Very common throughout. Flrs. - February April, Frts. - May-June.

Ethnovegetable use - Young fruits are used for the vegetable preparation.

Korku uses - Tender branches are heated on the fire, slightly burned, then are squeezed and liquid collected. This is put in ear to get relief from severe earache. Leaf decoction used to wash bleeding piles.

\section{Launea procumbens (Roxb.) Ramayya \& Rajgopal ASTERACEAE (Kor. Pathri)}

Occurrence - Very common throughout. Flrs. \& Frts. - July -October.

Ethnovegetable use - Young leaves are used for the vegetable preparation. Korku uses - Leaf juice applied over scabies.

Leea asiatica (L.) Ridsdell LEEACEAE (Kor. Dupu) Occurrence - Frequent, abundant at Dhakna and Harisal localities. Flrs. \& Frts. - October - December

Ethnovegetable use - Tubers are used for the vegetable preparation.

Korku uses - Tuber powder taken internally for elephantiasis. Root used as cure of Guinea worm.

Leea macrophylla Roxb. LEEACEAE (Kor-- Dupu, Mar.Dinda)

Occurrence - Frequent, abundent at Koktu, Dolar, Dhakna and Harisal localities. Flrs. \& Frts. -October - December

Ethnovegetable use - Young leaves are used for the vegetable preparation.

Korku uses - Tuber powder taken internally for elephantiasis. Fresh tuber paste applied over skin affections, leucoderma and cancerous growth. Root used as a cure of Guinea worm. Root paste applied over boils. 
Oxalis latifolia Kunth. OXALIDACEAE (Kor. Teen patti, Tenpaku)

Occurrence - Abundant in Coffee plantations.

Flrs. \& Frts. - April - June and October - December.

Ethnovegetable use - Leaves are sour in taste and used for the vegetable preparation.

Korku uses - Leaf juice given against acidity. Leaves as vegetables.

\section{Plumbago zeylanica L. PLUMBAGINACEAE}

(Kor.- Chitur)

Occurrence - Frequent in all localities; in forest undergrowth, especially along gullies and streams.

Flrs. \& Frts. - August - January

Ethnovegetable use - Young leaves are used for the vegetable preparation.

Korku uses - Root powder given in stomach disorders. Leaf juice applied in skin diseases. Leaf decoction supposed to increase immunity if taken daily. Leaves used as vegetable

\section{Schleichera oleosa(Lour.) Oken SAPINDACEAE}

(Kor. Baru)

Occurrence - Frequent, dense forest localities.

Flrs. \& Frts. - October - December

Ethnovegetable use - Young leaves are used for the vegetable preparation.

Uses - Bark decoction in constipation.

\section{RESULTS \& DISCUSSION}

A total of 189 ethnomedicinally important plants from Melghat were surveyed using a schedule to assess the knowledge, availability and consumption pattern of wild leafy vegetables. The study revealed 30 ethnovegetable plants of regular use in the food preparation of Korku. The diversity of wild leafy vegetables being use by the local inhabitants is 30 species belonging to 20 genera and 17 families. The majority of ethnovegetable plants were herbs the majority of the ethnovegetable plants used by Korku tribe in the study area were collected raw from the forest as wild and not cultivated ones. The study indicated that the knowledge is to be transferred properly by old people to younger generation and should be trained in collection and processing of such wild ethnovegetables. The record of 30 ethnovegetable plant species shows that Korku of Melghat is a distinct tribe. Another feature of Korku usage of plants as drugs is that the use of monocots is frequent in their system as compared to other tribes. Here, out of 30 plant species, 08 are from monocot.
The companionship between tribals and plants plays an important role. Tribal communities conserve, preserve and protect plants by their customs and tradition reflected in various rituals, mostly the tribals harvest plants or vegetables after offering them and used them as and when required. Nature offers many resources to enjoy their livelihood with forests. (Dovie DBK et al, 2002)

According to Bhumkas of Melghat wild leafy vegetables helps in increasing quantity and quality of blood. Today modern analytical techniques proved the same which is due to high content of Iron and other minerals in the green leafy vegetables. The majority of $\mathrm{d}$ edible forest produce eaten typically have High sugars, proteins, starch and, carbohydrates. (Sing \& Garg, 2006)

Almost every Korku family collects the seeds for next year plantation and worships at least one plant as family plant, which will be never cut by any of the family member. Thus they contribute to biodiversity conservation through their rituals (Devarkar, 2001).

\section{CONCLUSION}

The application of traditional knowledge by Korku tribe is very much restricted to their community and locality specific. Korku are very shy and conservative. Because of which it was very difficult to collect the information regarding uses of plants. Moreover, it is tedious as this knowledge comes from their ancestors through experience and practice. The knowledge of plants is not easily transferred even to their son till elderly person confirms his attitude, interest and ability to serve the community. This service is never for monetization or for economic benefits but for the conservation of nature. (Dovie DBK et al, 2007).

The present study shows that many nonagriculture plants species are used by Korku as their vegetables. Majority of them are leafy vegetables. These wild vegetable either handpicked or directly harvested from fields. No trading practices observed during this study but people can borrow or donate excess amount of vegetable to their neighbors. This definitely adds social values to their living.

\section{ACKNOWLEDGEMENTS}

I am very much thankful to all the informants, medicine men (Bhumkas) who have willingly shared their herbal knowledge with me, which encouraged me to take up this survey, may be called treasure in view of the healthcare and the nutrition for next generations. I am grateful to the Director, Govt. Institute of Science and Humanities, Amravati, Maharashtra (India) for encouragement, facilities 
and their constructive support during this period. Financial support to continue the work from TSBF-CIAT/GEF/UNEP is thankfully acknowledged. Also grateful to the Director, Botanical Survey of India, Pune for providing identification service for the herbarium specimens and extending Library facilities.

\section{REFERENCES}

Anonymous, 1968. Maharashtra State Gazetteers (Govt. of Maharashtra) Amravati District (Revsd. Edn.) Directorate of Government Printing, Stationery and Publications, Maharashtra State. 138-152.

Anonymous, 2001. Population Census- 2001. Delhi: Office of the Registrar General.

Anonymous, 1993. Scientific and Ecological Expedition of Nanda Devi. Dehradun: Wildlife Institute of India.

Bhogaonkar P Y \& Devarkar V D, 1999. Additions to the Flora of Melghat (Some rare and Uncommon Plants). Technical Bulletin No. VII. The Directorate Project Tiger Melghat, Amravati. (Maharashtra, India.)

Bussman R W, Sharon D, 2006. Traditional medicinal plant use in Northern Peru: tracking two thousand years of healing culture. Journal of Ethnobiology and Ethnomedicine, 2:47.

Bussmann R W, Gilbreath G G, Solio J, Lutura M, Lutuluo R, Kunguru K, Wood N, Mathenge S G, 2006. Plant use of the Maasai of Sekenani Valley, Maasai Mara, Kenya. Journal of Ethnobiology and Ethnomedicine, 2:22. https://doi.org/10.1186/1746-4269-2-22

Chweya J A, Eyzaguirre P B, 1999. The Biodiversity of Traditional Leafy Vegetables. Rome: International Plant Genetic Resources Institute.

Dhore M A \& P A Joshi, 1988. Flora of Melghat Tiger Reserve. Directorate, Project Tiger Melghate, Paratwada, Distt. Amravati, Maharashtra.

Dhyani D, Maikhuri R K, Rao K S, Kumar L, Purohit V K, Sundriyal M, Saxena KG, 2007. Basic nutritional attributes of Hippophae rhamnoides (seabuckthorn) populations from Uttarakhand Himalaya, India. Current Science, 92:1148-1152.

Dovie DBK, Shackleton C M, Witkowski ETF, 2007. Conceptualizing the human use of wild edible herbs for conservation in South African communal areas. Journal of Environmental Management, 84:146-156. https://doi.org/10.1016/j.jenvman.2006.05.017

Dovie DBK, Shackleton C M, Witkowski ETF 2002. Direct-use values of woodland resources consumed and traded in a South African village. International Journal of Sustainable Development and World Ecology, 9:269-283. https://doi.org/10.1080/13504500209470122

Gamble J S, 1919. Flora of Presidency of Madras. Vol I - II Kew - Britain. Grivetti L E \& Ogle B M, 2000. Value of traditional foods in meeting macro- and micro-nutrient needs: the wild plant connection. Nutrition Research Reviews, 13:31-46. https://doi.org/10.1079/095442200108728990

Hajra P K, 1983. A Contribution to the Botany of Nanda Devi National Park. Howrah: Botanical Survey of India.

Heever E \& Coertze A F, 2000. Indigenous Leaf Crops A2-Cleome. Pretoria: Agricultural Research Council.

Hooker J D, 1872-1897. The Flora of British India. Vol. I - VII. London.
Indurkar R N, 1992. Settlement of the Erstwhile Forest Villages in Melghat. Two Decades of Project Tiger, Melghat. (1973-1993). Publicity \& Information Officer. Pune.

Jansen van Rensburg W S, Venter S L, Netschluvhi T R, Heever E, Vorster H J, de Ronde J A, 2004. Role of indigenous leafy vegetables in combating hunger and malnutrition. South African Journal of Botany, 70:52 59. https://doi.org/10.1016/S0254-6299(15)30268-4

Kala C P, Rao K S, Maikhuri R K, Negi K S, 2003. Comparative assessment of the Valley of Flowers National Park and its adjacent areas in Chamoli district of Uttaranchal. The Indian Forester, 129:1085-1089.

Kala C P, 2007. Local preferences of ethnobotanical species in the Indian Himalaya: Implications for environmental conservation. Current Science, 93:1828-1834

Kala C P, 2007. Prioritization of cultivated and wild edibles by local people in the Uttaranchal hills of Indian Himalaya. Indian Journal of Traditional Knowledge, 6:239-243.

Kunwar R M, Nepal B K, Kshhetri H B, Rai S K, Bussmann R W, 2006 Ethnomedicine in Himalaya: a case study from Dolpa, Humla, Jumla and Mustang districts of Nepal. Journal of Ethnobiology and Ethnomedicine, 2:27. https://doi.org/10.1186/1746-4269-2-27

Ladkat N S \& R D Chopkar, 1992. Peoples of Melghat. Two Decades of Project Tiger, Melghat. (1973-1993). Publicity \& Information Officer, Pune

Lindeberg S, Cordain L, Eaton S B, 2003. Biological and clinical potential of a paleolitic diet. Journal of Nutritional and Environmental Medicine, 13:149-160. https://doi.org/10.1080/13590840310001619397

Maikhuri R K, Nautiyal S, Rao K S, Semwal R L, 2000. Indigenous knowledge of medicinal plants and wild edibles among three tribal sub communities of the central Himalayas, India. Indigenous Knowledge and Development Monitor, 8:7-13.

Maikhuri R K, Rao K S, Chauhan K, Kandari L S, Prasad P, Rajasekharan C, 2003. Development of marketing of medicinal plants and other forest products - can it be a pathway for effective management and conservation? The Indian Forester, 129:169-178.

Mukherjee A K, 1984. Flora of Pachmarhi \& Bori Reserves. Botanical Survey of India, Calcutta. India.

Naik V N, 1998. Flora of Marathwada. Vol. I \& II Amrut Prakashan, Aurangabad, India.

Nautiyal S, Maikhuri R K, Rao K S, Saxena K G, 2003. Ethnobotany of the Tolch ha bhotiya tribe of the bufferzone villages in Nanda Devi Biosphere Reserve, India. Journal of Economic and Taxonomic Botany, 27:119-141.

- $\quad$ Nautiyal S, Maikhuri R K, Rao K S, Saxena K G, 2001. Medicinal plant resources in Nanda Devi Biosphere Reserve in the central Himalaya. Journal of Herbs, Spices and Medicinal Plants 2001, 8:47-64. https://doi.org/10.1300/J044v08n04 06

Naithani B D, 1984. Flora of Chamoli. Howrah: Botanical Survey of India.

- $\quad$ Negi C S, Nautiyal S, Dasila L, Rao K S, Maikhuri R K, 2017.

Ethnomedicinal plant uses in a small tribal community in a part of central Himalaya, India. Journal of Human Ecology, 14:23-31. https://doi.org/10.1080/09709274.2003.11905592

- $\quad$ Nordeide M B, Hatloy A, Folling M, Lied E, Oshoug A 1996. Nutrient composition and nutritional importance of green leaves and wild foods in 
an agricultural district, Koutiala, in Southern Mali. Int J Food Sci Nutr, 47(6):455-468. https://doi.org/10.3109/09637489609031874

Ogoye-Ndegwa C, Aagaard-Hansen J, 2003. Traditional gathering of wild vegetables among the Luo of western Kenya - A nutritional anthropology project. Journal of Ecology of Food Nutrition, 42:69-89. https://oi.org/10.1080/03670240303114

Orech F O, Aagaard-Hansen J, Friis H, 2007. Ethnoecology of traditional leafy vegetables of the Luo people of Bondo district, western Kenya. Int J Food Sci Nutr, 58(7):522-530. https://doi.org/10.1080/09637480701331163

Patel R I, 1968. Forest Flora of Melghat. Prabhat Press, Meerat.

Pieroni A, Houlihan L, Ansari N, Hussain B, Aslam S, 2007. Medicinal perceptions of vegetables traditionally consumed by south-Asian migrants living in Bradford, Northern England. Journal of Ethnopharmacology, 113:100-110. https://doi.org/10.1016/j.jep.2007.05.009

Pohar J D, 1981. Korku Lokgeetonka Sahityik Adhyayan, Ph. D. Thesis. Nagpur University. Nagpur.

Samant S S, Dhar U, 1997. Diversity, endemism and economic potential of wild edible plants of Indian Himalaya. International Journal of Sustainable Development and World Ecology, 4:179-191.

Samant S S, Rawal R S, Dhar U, 2007. Diversity, extraction and status of fodder species in Askot wildlife sanctuary, west Himalaya, India. The International Journal of Biodiversity Science and Management, 2:29-42. https://doi.org/10.1080/17451590609618097

Scherrer A M, Motti R, Weckerle C S, 2005. Traditional plant use in the areas of Monte Vesole and Ascea, Cilento National Park (Campania, Southern Italy). Journal of Ethnopharmacology, 97:129-143. https://doi.org/10.1016/j.jep.2004.11.002

Shackleton SE, Dzerefos C M, Shackleton C M, Mathabala F R, 1998. Use and trading of wild edible herbs in central lowveld savannah region, South Africa. Economic Botany, 52:251-259. https://doi.org/10.1007/BF02862142

Sharma B D, Karthikeyan and N P Singh, 1996. (Ed.). Flora of Maharashtra State-Monocotyledons. Botanical Survey of India, Calcutta.

Singh N P \& S. Karthikeyan, 2000. Flora of Maharashtra StateDicotyledones - Vol.1. Botanical Survey of India. Calcutta. India.

Singh V, Garg A N, 2006. Availability of essential trace elements in Indian cereals, vegetables and spices using INAA and the contribution of spices to daily dietary intake.Food Chemistry, 94:81-89. https://doi.org/10.1016/j.foodchem.2004.10.053

Sundriyal M, Sundriyal R C, 2003. Underutilized edible plants of the Sikkim Himalaya: Need for domestication. Current Science, 85:731-736.

Sundriyal M, Sundriyal R C, 2001. Wild edible plants of the Sikkim Himalaya: Nutritive values of selected species. Economic Botany, 55:377390. https://doi.org/10.1007/BF02866561

Vainio-Mattila K, 2000. Wild vegetables used by the Sambaa in the Usmbara Mountains, NE Tanzania. Annales Botanici Fennici, 37:57-67.

C 2018| Published by Plantae Scientia 